\title{
Bibliometric Analysis of Publications in the Scopus Database: A Study at Diponegoro University during 2014-2018
}

\author{
Yos Johan Utama ${ }^{1}$, Budi Setiyono ${ }^{2}$, Jamari ${ }^{3}$, Mohammad Tauviqirrahman ${ }^{3,}$, and Heru Susanto ${ }^{4}$ \\ ${ }^{1}$ Department of Law, Faculty of Law, Diponegoro University, Semarang - Indonesia \\ ${ }^{2}$ Department of Governmental Science, Faculty of Social and Political Sciences, Diponegoro Semarang - Indonesia \\ ${ }^{3}$ Department of Mechanical Engineering, Faculty of Engineering, Diponegoro University, Semarang - Indonesia \\ ${ }^{4}$ Department of Chemical Engineering, Faculty of Engineering, Diponegoro University, Semarang - Indonesia
}

\begin{abstract}
This paper presents the strategy of Diponegoro University to increase its research productivity towards the world-class university. Bibliometric indicators are employed to characterize the research activities of Diponegoro University, Indonesia with production in the period of 2014-2018 in publications that are indexed in the Scopus database. The number of documents and their comparison with other universities, and productive authors are of particular interest. The results reflect that the university documents improve significantly during the research time frame. In comparison with other top ten universities in Indonesia, for the last five years, Diponegoro University has achieved the fastest rate of publication (up to $471 \%$ ). However, compared to other universities in neighboring countries, Diponegoro University is still left behind. In addition, it is shown that prolific authors contributing to documents in Scopus are uneven in terms of origin of faculty. Based on these results, a recommendation with respect to the research productivity is discussed in this paper.
\end{abstract}

Keywords: Bibliometric; Citation; Research productivity; World Class University.

\section{Introduction}

Recently, the term "world class university" has become a catchy phrase, in creating and implementing advanced knowledge, developing the capacity for intellectual and technological leadership, and serving the needs of society in the global education marketplace [1]. This term often refers to the most prestigious research university. Building a world-class university in competitive communities has become a challenging task for universities worldwide. One of the calibrated performance indicators of a world-class university is research productivity. With the birth of Scopus in 2004 as one of database of scientific documents, the research productivity of an institution can be easily measured through the production of published works. Since its launching, Scopus has attracted many attentions of universities, research institutes, governments, and world researchers. Scopus covers nearly 36,377 titles from approximately 11,678 publishers, of which 34,346 are peer-reviewed journals in top-level subject fields such as life sciences, social sciences, physical sciences, and health sciences.

In Indonesia, since the Ministry of Research, Technology, and Higher Education made a policy to assess Indonesian universities' research, the growth of the production of publication indexed in Scopus among Indonesian authors has been significantly increasing.
However, from a scientific point of view, based on a literature survey, only a few authors have attempted to make efforts in exploring and examining the research productivity in Indonesian universities based on the available data from the Scopus database. It is worth to mention the early work of Jati and Dominic [2], Darmadji et al. [3, 4] and Prasojo et al. [5] who explored in more detail and gave an insight the national research performance through several parameters such as number of documents, most-cited documents, prolific authors, etc.

Therefore, in order to complement the previously published works, this paper aims to provide an overview of research productivity with a study case in Diponegoro University by using bibliometric methods. The main focus of this research is to explore how Diponegoro University becomes top in the Indonesian universities league seeking to achieve world-class status with respect to research productivity. To achieve the objectives, an advanced search of locating documents published in conference proceedings, book chapters and journals indexed in Scopus via bibliometric assessment is carried out. This paper is divided into three main sections. Firstly, the background of the research is presented. The second point explores the database and the methodology used to get references. Subsequently, in the third part, the basic bibliometric indicators for the publications of Diponegoro University are demonstrated in detail.

* Corresponding author: mohammad.tauviqirrahman@,ft.undip.ac.id 
Finally, in the last section, the discussion associated with a recommendation as well as the final conclusion is highlighted.

\section{Methodology}

Diponegoro University has been indexed in Scopus with Affiliation ID of 60069385. For indexing, in addition to the name of Diponegoro University, the use of two other official names of the affiliation, i.e. Universitas Diponegoro and University of Diponegoro have been observed. Therefore, only documents listed under affiliation ID are collected. In this work, the empirical material employed is based on Scopus multidisciplinary index combined with SCImago Institution Ranking (SIR) database. The quantitative research approach is adopted in the form of bibliometric to assess the documents of Diponegoro University in Scopus. The data is collected during the time frame from the beginning of 2014 to the end of 2018. In this way, the development of the number of documents as well as other data types can be analyzed through the feature of "Analyze search result" in Scopus.

In detail, the bibliometric indicators calculated to determine the research productivity of Diponegoro University are the following:

a) Number of documents published in scientific proceedings, book chapters, and journals and included in the Scopus database.

b) Percentage of the documents based on subjects.

c) Top productive authors based on number of documents.

d) Number of documents from other top universities in Indonesian and neighboring countries.

It should be noted that for all following results shown here, the source of publication is based on documents from conference proceedings, book chapters, and journals that are in coverage of Scopus. This approach is applicable to all subject areas, so all disciplines are susceptible to being analyzed.

\section{Results}

\subsection{Documents}

In the Scopus database, the scientific article is the most widely used form to share. Figure 1 depicts the total scholarly papers by faculty members of Diponegoro University indexed in Scopus for the last five years. It is found that in 2014, 746 documents affiliated with Diponegoro University are listed in the Scopus database. This number increased exponentially to 4,260 in 2018 . It means that during last five years, the increase in the publication is up to $471 \%$. This increase makes Diponegoro University be at $6^{\text {th }}$ rank position in 10 top universities in Indonesia in terms of number of articles in Scopus. It should be noted that based on Scopus database, in the beginning of Scopus' inclusion in 1973, Diponegoro University marks only 1 document in Scopus. It means that Diponegoro University takes time around 45 years to obtain the number of documents equal to 4,260 (see Fig 1 and Fig 2). As reflected in Fig 2 , another interesting result is observed. Up to 2009 , the rate of publications in Scopus is relatively very slow. However, the opposite result is underlined for 10 last years. Starting from 2009, the publication increases significantly, and in a specific time frame (last five years), this growth is highlighted as depicted in Figure 1.

In order to describe the distribution of the subject area of documents in 2018, the analysis result is reflected in Fig 3. This subject area indicates the global topics of the researches conducted by authors affiliated with Diponegoro University. This result also reflects the publication strength of the university. Based on Fig 3, it can be seen that the engineering area gives the highest number of publications for the University (up to $15 \%$ or 1,411 articles). Later, with 1,322 articles (or $14 \%$ ) environmental science contributes to the growth of publication in the university. It is interesting to note that the social sciences area gives the contribution only up to $5 \%$. While this current issue requires further investigation, several points are a play. The most possible factor is that trends to publish their results for authors from the social sciences area are different from those from engineering area which not being of interest to an international journal. Based on this data, policy makers from the University as well as the Indonesian government should make mapping and evaluation which finally can encourage the faculty member from social sesciences area to publish more papers.

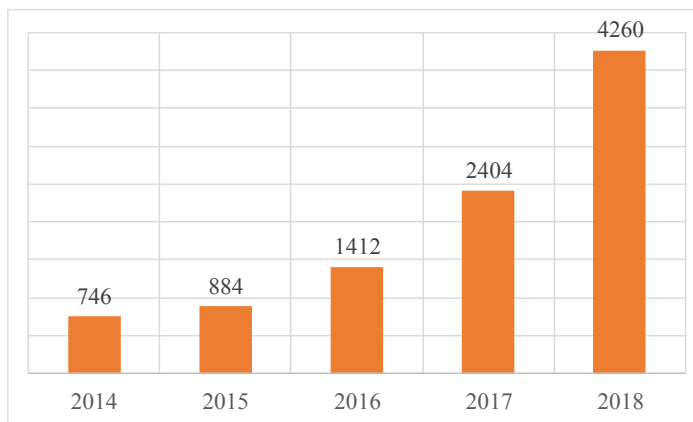

Fig. 1. Accumulated documents of Diponegoro University in Scopus, 2014-2018. Source: Scopus, accesses February 6, 2019.

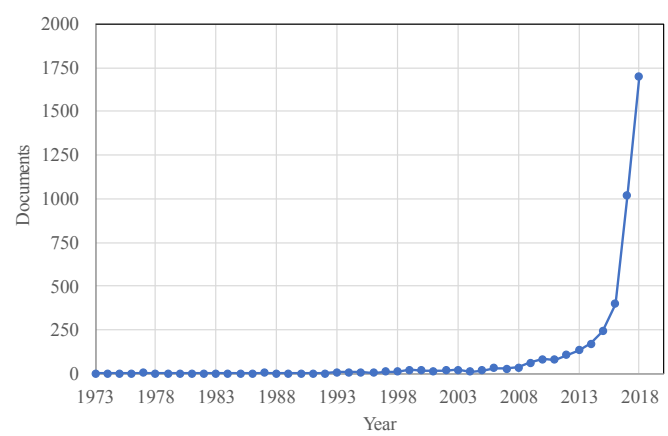

Fig. 2. Documents of Diponegoro University by year in Scopus, 1973-2018 


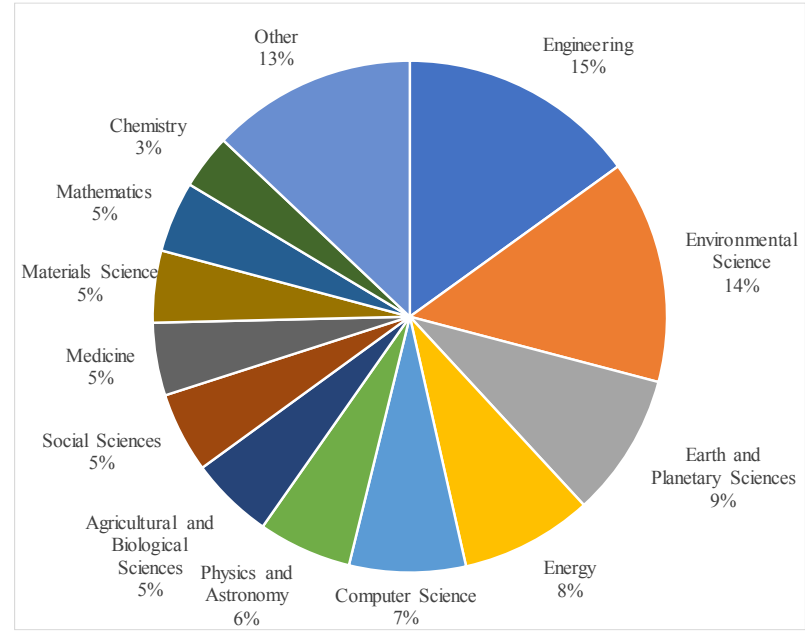

Fig. 3. Diponegoro University's Documents in Scopus Based on Subjects. Source: Scopus, accesses February 6, 2019

For more detail, the documents by year and their citations of the publications of Diponegoro University are summarized in Table 1. A citation is a reference to the source of information which may express the quality of the paper. Based on Table 1, it can be seen that for last five years, the number of citations is relatively constant. Only in 2018, the total citation is low, i.e., 276 citation. However, this number is understandable because the number of published works in 2019 from researchers around the world is still low, and of course, the citation to the articles affiliated with Diponegoro University is also limited. Another finding based on Table 1 is that Average citation per paper (ACPP) by year tends to decrease. It indicates that fewer researchers cited the papers written by Diponegoro University authors. Thus, in the future, there should be more efforts and/or policies from the University to encourage the faculty's member to publish their research results in better journal (i.e. higher quartile of journal). As discussed by Darmadji [4], the higher the quality of journal (marked by the higher quartile of the journal) for publication, the more likely the paper cited by more researchers.

Table 1. Documents per Year of Diponegoro University. Source: Scopus, accesses February 6, 2019

\begin{tabular}{|l|l|l|l|}
\hline Year & Documents & Citation & $\begin{array}{l}\text { ACPP (Average } \\
\text { Citation per } \\
\text { Paper) }\end{array}$ \\
\hline 2014 & 172 & 962 & 5.6 \\
\hline 2015 & 241 & 805 & 3.3 \\
\hline 2016 & 399 & 855 & 2.1 \\
\hline 2017 & 1,019 & 806 & 0.8 \\
\hline 2018 & 1,681 & 276 & 0.2 \\
\hline
\end{tabular}

\subsection{Productive authors}

Based on Scopus data, to the end of the 2018 there are 3,616 authors affiliated with Diponegoro University whose contribution to the documents in Scopus. In detail, the top 10 prolific authors of Diponegoro
University in terms of the number of documents are listed in Table 2. It can be shown that the most prolific author is Jamari with 126 indexed documents, followed by Sonny Winoto with 102 documents. However, with respect to the $h$-index indicator, Heru Susanto is the author whose highest $h$-index, that is, 15 with 1,587 citations. It is interesting to note that the prolific authors contributing to scholarly articles in Scopus is uneven in terms of origin of faculty. Most of the 10 ten authors are from engineering faculty. It is noted that only Sultana is from Medicine area.

\subsection{Comparison with other top Indonesian universities}

Regarding with the position of Diponegoro University among other top Indonesia universities, it is shown that at the national level Diponegoro University stands at the $6^{\text {th }}$ place with 4,260 scholarly publications as summarized in detail in Table 3. The result also reflects that there is a huge gap between the scholarly publications affiliated with University of Indonesia ( $1^{\text {st }}$ rank) and that with Diponegoro University. For example, in 2018, the documents by authors of University of Indonesia indexed in Scopus is 12,128 or nearly three times larger than that of Diponegoro University. However, for the years covered by this study, the rate of publications of Diponegoro University is the highest (up to $471 \%$ ) among other top ten universities. This number outperforms the achievement of University of Indonesia (247\%), Bandung Institute of Technology (147\%), Gadjah Mada University (272\%), Bogor Agricultural University (203\%) and Sepuluh Nopember Institute of Technology (300\%). On the other words, if the research productivity of Diponegoro University is kept constant and perhaps, better, so the scholarly articles for next five years may exceed the performance of other top Indonesian institutions.

\subsection{Comparison with other top universities in neighboring countries}

At the international level, the comparison to top universities in neighboring countries is performed as shown in Table 4. In this section, top university in each country is chosen based on the number of the scholarly publications recorded in Scopus. Comparison between top International universities shows that Diponegoro University is still extremely left behind in terms of the publications. Compared to University of Malaya as the best university in Malaysia, for example, the difference of publications is around $1,000 \%$ by year. The causes for this need deeper investigation. From the public policy point of view, this means that Indonesian universities, specifically Diponegoro University should perform extra efforts to catch-up in terms of the publication growth. 
Table 2. Diponegoro University's Top 20 Authors Based on Number of Documents.

Source: Scopus, accesses February 6, 2019.

\begin{tabular}{|c|c|c|c|c|c|c|c|}
\hline No & Author & Faculty & Subject & Documents & Citation & ACPP & $h$-index \\
\hline 1 & Jamari, J. & Engineering & $\begin{array}{l}\text { Engineering; Physics and } \\
\text { Astronomy; Materials Science }\end{array}$ & 126 & 350 & 2.8 & 11 \\
\hline 2 & Winoto, Sonny H. & Engineering & $\begin{array}{l}\text { Engineering; Physics and } \\
\text { Astronomy; Chemical } \\
\text { Engineering }\end{array}$ & 102 & 688 & 6.7 & 14 \\
\hline 3 & Hadiyanto, $\mathrm{H}$. & Engineering & $\begin{array}{l}\text { Environmental Science; Earth } \\
\text { and Planetary Sciences; } \\
\text { Energy }\end{array}$ & 98 & 513 & 5.2 & 12 \\
\hline 4 & Ismail, Rifky & Engineering & $\begin{array}{l}\text { Engineering; Physics and } \\
\text { Astronomy; Computer Science }\end{array}$ & 78 & 157 & 2.0 & 6 \\
\hline 5 & $\begin{array}{l}\text { Bayuseno, } \\
\text { Athanasius P. }\end{array}$ & Engineering & $\begin{array}{l}\text { Engineering; Physics and } \\
\text { Astronomy; Materials Science }\end{array}$ & 75 & 201 & 2.7 & 6 \\
\hline 6 & Purwanto, P. & Engineering & $\begin{array}{l}\text { Environmental Science; Social } \\
\text { Sciences; Energy }\end{array}$ & 72 & 357 & 5.0 & 6 \\
\hline 7 & $\begin{array}{l}\text { Tauviqirrahman, } \\
\text { M. }\end{array}$ & Engineering & $\begin{array}{l}\text { Engineering; Physics and } \\
\text { Astronomy; Materials Science }\end{array}$ & 72 & 141 & 2.0 & 7 \\
\hline 8 & $\begin{array}{l}\text { Riyadi, Munawar } \\
\text { A. }\end{array}$ & Engineering & $\begin{array}{l}\text { Computer Science; } \\
\text { Engineering; Physics and } \\
\text { Astronomy }\end{array}$ & 65 & 121 & 1.9 & 7 \\
\hline 9 & $\begin{array}{l}\text { Faradz, Sultana } \\
\text { M.H. }\end{array}$ & Medicine & $\begin{array}{l}\text { Medicine; Biochemistry, } \\
\text { Genetics and Molecular } \\
\text { Biology; Immunology and } \\
\text { Microbiology }\end{array}$ & 63 & 792 & 12.6 & 14 \\
\hline 10 & Susanto, Heru & Engineering & $\begin{array}{l}\text { Chemical Engineering; } \\
\text { Environmental Science; } \\
\text { Engineering }\end{array}$ & 63 & 1,587 & 25.2 & 15 \\
\hline
\end{tabular}

Table 3. Top 10 Universities in Indonesia in terms of Scholarly paper in Scopus, 2014-2018. Source: Scopus, accesses February 6, 2019.

\begin{tabular}{|c|l|l|c|c|c|c|c|}
\hline \multirow{2}{*}{ No } & \multirow{2}{*}{ Institution } & \multicolumn{5}{|c|}{ Number of Documents } \\
\cline { 3 - 7 } & & & 2014 & 2015 & 2016 & 2017 & 2018 \\
\hline 1 & University of Indonesia & Jakarta & 3,484 & 4,123 & 5,950 & 8,494 & 12,128 \\
\hline 2 & $\begin{array}{l}\text { Bandung Institute of } \\
\text { Technology }\end{array}$ & Bandung & 4,094 & 5,033 & 7,058 & 8,893 & 11,169 \\
\hline 3 & Gadjah Mada University & Yogyakarta & 1,981 & 2,741 & 4,356 & 5,504 & 7,455 \\
\hline 4 & $\begin{array}{l}\text { Bogor Agricultural } \\
\text { University }\end{array}$ & Bogor & 1,551 & 1,917 & 2,775 & 3,723 & 4,714 \\
\hline 5 & $\begin{array}{l}\text { Sepuluh Nopember Institute } \\
\text { of Technology }\end{array}$ & Surabaya & 1,115 & 1,389 & 2,124 & 2,933 & 4,471 \\
\hline 6 & Diponegoro University & Semarang & 746 & 884 & 1,412 & 2,404 & 4,260 \\
\hline 7 & Brawijaya University & Malang & 697 & 1,032 & 1,500 & 1,991 & 3,444 \\
\hline 8 & Padjadjaran University & Bandung & 669 & 886 & 1,304 & 1,911 & 2,918 \\
\hline 9 & Sebelas Maret University & Surakarta & 301 & 455 & 904 & 1,593 & 2,823 \\
\hline 10 & University of Sumatra Utara & Medan & 221 & 283 & 463 & 1,055 & 2,754 \\
\hline
\end{tabular}

Table 4. Top Universities in South-East Asia Based on Scholarly Articles in Scopus, 2014-2018. Source: Scopus, accesses February 6, 2019.

\begin{tabular}{|c|l|l|c|c|c|c|c|}
\hline \multirow{2}{*}{ No } & \multirow{2}{*}{ Institution } & \multirow{2}{*}{ Country } & \multicolumn{5}{|c|}{ Number of Documents } \\
\cline { 4 - 8 } & & & 2014 & 2015 & 2016 & 2017 & 2018 \\
\hline 1 & $\begin{array}{l}\text { National University of } \\
\text { Singapore }\end{array}$ & Singapore & 103,292 & 111,391 & 119,391 & 128,503 & 137,587 \\
\hline 2 & University of Malaya & Malaysia & 29,772 & 34,317 & 39,018 & 43,408 & 47,351 \\
\hline 3 & Mahidol University & Thailand & 24,085 & 26,179 & 28,613 & 31,294 & 34,151 \\
\hline 4 & $\begin{array}{l}\text { University of the Philippines } \\
\text { Diliman }\end{array}$ & Philippines & 3,091 & 3,376 & 3,760 & 4,164 & 4,573 \\
\hline 5 & Diponegoro University & Indonesia & 746 & 884 & 1,412 & 2,404 & 4,260 \\
\hline
\end{tabular}




\subsection{University efforts to increase the publication}

With respect to the efforts of Diponegoro University towards World Class University, Diponegoro University has implemented many strategies to enhance the research productivity of its faculty members. Firstly, the financial barriers for researchers have been solved by University by providing more sufficient funding to stimulate the research climate via various research schemes. All of these schemes can be accessed by faculty members. Secondly, in the last five years the financial incentive for published papers in Scopus has been introduced. Furthermore, each year the rewards for most productive authors was also given to fire and encourage the spirit of other faculty members. Thirdly, in order to guide the faculty members in writing the scientific articles, University through Institute for Research and Community Services (LPPM) periodically (4-6 times per year) carried out the activity of manuscript writing clinic for all University civitas including the students both under graduate and graduate students. In addition, the availability of manuscript center in LPPM guided by senior researchers has helped the faculty members of Diponegoro university in how to write the article in terms of English usage, how to determine the appropriate journal, and things related to manuscript submission to journals. This specific treatment may allow the researchers to be more confident in submitting their result research to classier journal. As a note, current policy of University obliges the graduate students (master and doctoral program) to have at least one Scopus indexed article prior to the final examination. It seems that the impact of these strategies has proven to enhance the publication rate of Diponegoro University in Scopus data in general.

\section{Concluding remarks}

In this study, a bibliometric study based on Scopus database was performed to assess the research productivity of Diponegoro University during 20142018. The result reveals that Diponegoro University has improved an absolute number of overall publications. A notable mention of this research result is that during the years covered in this study the publication rate achieved by Diponegoro University is the largest compared to other top universities in Indonesia.

Other interesting result based on this study is that as mentioned in previous section for the scholarly documents recorded in Scopus, the publications in engineering area gives the highest contribution to documents. This number is not comparable to documents in social science area. With respect to the relatively low publication in background of social science, there are many reasons why this issue could happen; the authors did not investigate it in the present work. However, for a broader spectrum the reader can refer to the work of Nederhof [6] for detail possible reasons. Again, while this trend requires further investigation, considering the publications context in Diponegoro University, some recommendations can be breakdown. One of them is that
University can enhance the collaboration network with other institutions both local and international. By considering the unique geographical factors for collaboration leading to more interest for international researchers, the greater amount of research in social sciences area can be achieved in the future.

\section{References}

1. Philip G. Altbach, The Past, Present and Future of the Research University. In P. Altbach \& J. Salmi (Eds.), The Road to Academic Excellence: The Making of World-Class Research Universities (Washington: The World Bank, 2011)

2. H. Jati, D.D. Dominic, Procedia Comput. Sci. 124, 8 (2017)

3. A. Darmadji, L.D. Prasojo, F.A. Kusumaningrum, Y. Andriansyah Y, Curr. Sci. 115(4), 6 (2018)

4. A. Darmadji A, L.D. Prasojo, Y. Riyanto, F.A. Kusumaningrum, Y. Andriansyah, COLLNET J. Sci. Inform. Manag. 12(1), 23 (2018)

5. L.D. Prasojo, R. Fatmasari, E. Nurhayati, A. Darmadji, F.A. Kusumaningrum, Y. Andriansyah, Data in Brief 22, 11 (2019)

6. A.J. Nederhof, Scientometrics 66(1), 20 (2006) 